\title{
INTERFERENSI SINTAKSIS BAHASA KATINGAN TERHADAP BAHASA INDONESIA DI SMP NEGERI 1 KATINGAN TENGAH KABUPATEN KATINGAN KALIMANTAN TENGAH
}

\author{
Irni Cahyani dan Riduan Saberan \\ STKIP PGRI Banjarmasin Kalimantan Selatan. \\ Email: irnicahyani@stkipbjm.ac.id; riduansaberan@stkipbjm.ac.id
}

\begin{abstract}
The purpose of this study is negative transfer better known by the term interference in the acquisition of a second language. The term interference refers to two different linguistic phenomena, namely psychological interference and sociolinguistic interference. Psychological interference refers to the influence of old habits as a result of learning something about something that is being studied. While sociolinguistic interference refers to the interaction of the language, such as loan or password change. Factors that cause interference is the factor of contact language and language skills. The result of research on the syntactic interference aspects of Katingan language to Indonesian language is found two types of syntactic interference which is contained in oral and written language of students of SMPN 1 Katingan Tengah, among others: (1) Interference phrase to Indonesian language and (2) Interference sentence to Indonesian language.
\end{abstract}

Key word: interference, syntax, katingan, speak, writing.

\begin{abstract}
ABSTRAK
Tujuan penelitian ini ialah transfer negatif lebih dikenal dengan istilah interferensi dalam pemerolehan bahasa kedua. Istilah interferensi mengacu pada dua fenomena linguistik yang berbeda, yaitu interferensi psikologis dan interferensi sosiolinguistik. Interferensi psikologis mengacu kepada pengaruh kebiasaan lama sebagai hasil mempelajari sesuatu terhadap sesuatu yang sedang dipelajari. Sedangkan interferensi sosiolinguistik mengacu pada interaksi bahasa, misalnya pinjaman atau alih sandi. Faktor yang menyebabkan terjadinya interferensi adalah faktor kontak bahasa dan faktor kemampuan berbahasa. Hasil penelitian aspek interferensi sintaksis bahasa Katingan terhadap bahasa Indonesia yaitu ditemukan dua jenis interferensi sintaksis yang terdapat dalam bahasa lisan dan tulisan siswa SMPN 1 Katingan Tengah antara lain: (1) Interferensi frasa terhadap bahasa Indonesia dan (2) Interferensi kalimat terhadap bahasa Indonesia.
\end{abstract}

Kata kunci: interferensi, sintaksis, bahasa katingan, lisan, tulisan. 


\section{PENDAHULUAN}

Indonesia memiliki beragam bahasa, oleh sebab itulah masyarakat Indonesia merupakan masyarakat yang bilingual atau dwibahasa. Hal ini dapat terlihat dengan penggunaan dua bahasa dalam berkomunikasi selain menguasai bahasa Indonesia, yaitu bahasa nasional juga menguasai bahasa daerahnya masingmasing. Kedua bahasa tersebut kadangkadang digunakan secara bersamaan dalam situasi dan kondisi tertentu. Fenomena inilah yang mempengaruhi kemampuan berbahasa seseorang akibat kontak bahasa tersebut. Tidak hanya Indonesia yang memiliki keanekaragaman bahasanya, suku Dayak yang ada di Kalimantan pun memiliki beragam bahasa daerah. Salah satu bahasa daerah yang terdapat di Kalimantan Tengah adalah bahasa Katingan. Dinamakan bahasa Katingan, karena penuturnya berdiam di sepanjang sungai Katingan.

Bahasa adalah alat komunikasi yang dapat dipakai oleh seseorang untuk mengekspresikan gagasan maupun ide yang akan dituangkan dalam pikirannya. Ekspresi bahasa itu adalah menggambarkan keadaan seseorang tersebut atau penuturnya. Bahasa adalah salah satu ciri yang paling khas manusiawi yang membedakannya dari makhluk-makhluk lain. Bahasa dapat dikaji dari beberapa sudut dan memberikan perhatian khusus pada unsur-unsur bahasa yang berbedabeda dan pada hubungan-hubungan (struktur) yang membeda-bedakan pula (Rafiek, 2007: 49). Bahasa (language) menurut Kridalaksana (2001:21) adalah "sistem lambang bunyi yang arbitrer, yang dipergunakan oleh para anggota suatu masyarakat untuk bekerja sama, berinteraksi, dan mengidentifikasikan diri", sedangkan tuturan (narative) menurut Kridalaksana (2001:221) adalah wacana yang menonjolkan serangkaian peristiwa dalam serentetan waktu tertentu, bersama dengan partisipan dan keadaan tertentu.
Dengan adanya variasi-variasi bahasa tersebut terjadilah fenomena masyarakat yang bilingual atau multilingual akibat adanya kontak bahasa sekaligus juga merupakan kontak budaya. Dengan adanya masyarakat yang bilingual, maka terjadi peristiwa atau kasus yang disebut interferensi. Interferensi adalah terbawa masuknya unsur bahasa lain ke dalam bahasa yang sedang digunakan, sehingga tampak adanya penyimpangan kaidah dari bahasa yang sedang digunakan itu.

Interferensi itu sendiri berasal dari kata bahasa Inggris interference yang bermakna campur tangan. Interferensi berasal dari temuan Weinreich (1953) yang mengatakan bahwa interferensi sebagai suatu interaksi kebahasaan yang muncul ketika dua masyarakat bahasa melakukan kontak bahasa. Interferensi yang dikemukakan oleh Weinreich (dalam Rafiek, 2007:135) adalah penyimpangan norma-norma kebahasaan yang muncul pada seseorang bilingual menggunakan salah satu dari dua bahasa yang dikuasai dalam komunikasi nyata. Selaras dengan interferensi yang dikemukakan oleh Weinreich, Robert Lado (dalam Rafiek, 2007:136) mendefinisikan interferensi adalah kesulitan yang muncul dalam proses penguasaan bahasa kedua dalam hal bunyi, kata, atau konstruksi sebagai akibat perbedaan kebiasaan dengan bahasa pertama.

Pada mulanya interferensi itu hanya terbagi atas dua, yaitu interferensi sistemis dan interferensi perkembangannya. Interferensi sistemis adalah interferensi yang terjadi akibat performansi bahasa penutur yang mengakibatkan perubahan sistem bahasa tempat terjadinya interferensi. Sedangkan interferensi perkembangan adalah interferensi yang terjadi pada perkembangan belajar seseorang ketika belajar bahasa pertama atau belajar bahasa kedua. Interferensi ini disebut juga interferensi belajar (Rafiek, 2007:139). Jika kita perhatikan, interferensi yang terjadi pada suatu bahasa memiliki keuntungan dan kerugian seperti yang dikemukakan oleh Yanti (2011:69). Keuntungan dari 
interferensi yang dilakukan oleh penutur bahasa adalah antara lain dapat menambah khazanah kosakata dan juga memperkaya bahasa yang bersangkutan. Kerugian yang diakibatkan oleh interferensi yang dilakukan oleh penutur bahasa adalah dapat mempengaruhi dan mengacaukan struktur, sehingga dalam pemakaiannya terjadi penyimpangan bahasa tersebut.

Kerugian dari interferensi yang dilakukan oleh penutur bahasa atau disebut juga transfer negatif lebih dikenal dengan istilah interferensi dalam pemerolehan bahasa kedua. Istilah interferensi mengacu pada dua fenomena linguistik yang berbeda, yaitu interferensi psikologis dan interferensi sosiolinguitik. Menurut Dulay, et. Al (dalam Rafiek, 2007:139) bahwa interferensi psikologis mengacu kepada pengaruh kebiasaan lama sebagai hasil mempelajari sesuatu terhadap sesuatu yang sedang dipelajari. Sedangkan interferensi sosiolinguistik mengacu pada interaksi bahasa, misalnya pinjaman atau alih sandi. Faktor yang menyebabkan terjadinya interferensi adalah faktor kontak bahasa dan faktor kemampuan berbahasa. Interferensi disebabkan oleh faktor kontak bahasa pada masyarakat bilingual dan faktor penguasaan bahasa yang belum mantap pada pembelajar bahasa kedua atau pembelajar bahasa asing (Rafiek,2007:138). Hal ini sesuai dengan di lapangan, yakni pendapat guru bahwa masih terdapat kesalahan dalam berbahasa, baik itu kegiatan berbicara dan kegiatan tulis menulis. Hal itu yang membuat peneliti tertarik untuk melakukan ini. Contoh kesalahan yang terjadi akibat interferensi bahasa Katingan, yang ditemukan pada saat kegiatan tulis menulis bahasa Indonesia. "Aku sangat senang melihat padi yang ditanam aku dan ibu sudah manguning". Kata manguning di sini akibat interferensi bahasa Katingan yang tidak mengenal huruf/e/. Seharusnya dalam bahasa Indonesia menjadi menguning. Contoh lain adalah kata manugal seharusnya menugal.

\section{METODE PENELITIAN}

Metode yang digunakan dalam penelitian ini adalah metode kualitatif deskriptif. Metode kualitatif deskriptif sesuai untuk memahami interaksi sosial dan hanya dapat diuraikan kalau peneliti melakukan penelitian dengan cara berperan serta, wawancara mendalam terhadap interaksi sosial (Wahyu, 2012:21). Jadi, dapat dikatakan metode penelitian ini dalam mengumpulkan atau menyediakan data dan menganalisis data untuk mempelajari fenomena-fenomena kebahasaan yang terjadi. Jadi, penelitian ini menggunakan metode penelitian deskriptif yang memiliki beberapa ciri, antara lain (1) tidak mempersalahkan benar atau salah objek yang dikaji, (2) penekanan pada gejala aktual atau pada yang terjadi pada saat penelitian dilakukan, dan (3) biasanya tidak diarahkan untuk menguji hipotesis.

\section{HASIL DAN PEMBAHASAN}

\section{Aspek Interferensi Sintaksis}

Interferensi dalam bidang sintaksis juga ditemukan dalam penggunaan bahasa Indonesia. Penggunaan serpihan kata, frase, dan klausa di dalam kalimat juga dapat dikatakan interferensi pada tingkat kalimat.

\section{Interferensi Frasa}

\section{Data 1}

Sesampai di Makikit akupun gembira dengan gak sabar aku capat memarkirkan motorku dan mengajak teman-temanku untuk berjalan menuju riamnya. Ternyata orangnya banyak sekali kamipun antri berjalan menuju ke sana karena banyak berlibur ke situ.

Penggunaan akhiran -nya dipakai sebagai kata ganti yang menyatakan kepemilikan yang digabungkan dengan kata dasar. Selain sebagai kata ganti kepemilikan, akhiran -nya juga berfungsi untuk menunjukkan sesuatu. Dalam tulisan siswa di atas, pada kalimat kedua terdapat 
frasa ternyata orangnya, terdapat kesalahan berbahasa akibat pengaruh bahasa Katingan. Seharusnya perbaikan kalimat tersebut di bawah ini.

Sesampai di Makikit akupun gembira dengan gak sabar aku capat memarkirkan motorku dan mengajak teman-temanku untuk berjalan menuju riamnya. Ternyata pengunjungnya banyak sekali kamipun antri berjalan menuju ke sana, karena banyak berlibur ke situ.

\section{Interfensi Kalimat}

\section{Data 2}

Aku dan ibu pergi ke ladang, di ladang sana kami berdua bemalam.

Berdasarkan kalimat di atas, interferensi yang dilakukan oleh siswa dalam tulisannya adalah penggunaan di ladang sana. Pengaruh penggunaan bahasa daerah, yaitu di ladang hekau menjadi di ladang sana adalah keliru dalam bahasa Indonesia. Jadi, dapat dikatakan ladang sudah menunjukkan tempat, tanpa perlu ditambahkan kata sana. Perbaikan kalimat tersebut adalah $A k u$ dan ibu pergi ke ladang, di ladang kami berdua bermalam.

\section{Data 3}

Di perjalanan aku hampir jatuh dari motor, karena mehindari lobang karena jalan ke Makikit rusak sekali hampir 3 kali aku mau jatuh, untung saja aku bisa mengendalikannya. Di perjalanan hampir 2 jam, kami baru sampai ke Makikit dari Samba tadi itupun sudah laju kami.

Berdasarkan hasil tulisan siswa di atas terdapat kesalahan berbahasa yaitu dalam kalimat kedua, terdapat penggunaan sudah laju kami. Seharusnya sudah dengan kecepatan tinggi.

\section{Data 4}

Sesudah mandi kamipun berjalan ke pinggir untuk bersantai sambil melihat pemandangan, karena kelamaan duduk di pinggir akupun mengajak salah satu temanku untuk berjalan-jalan kami berkumpul, sesudah sampai tempat berkumpul kami dua temanku melihat teman kami yang lain sudah tidak ada kamipun menuju parkiran dan bergegas untuk pulang.

Berdasarkan tulisan di atas terdapat kesalahan berbahasa akibat pelesapan dalam kata dua seharusnya adalah berdua. Seharusnya perbaikan kalimat tersebut adalah Sesudah mandi kamipun berjalan ke pinggir untuk bersantai sambil melihat pemandangan, karena kelamaan duduk di pinggir akupun mengajak salah satu temanku untuk berjalan-jalan kami berkumpul, sesudah sampai tempat berkumpul kami berdua temanku melihat teman kami yang lain sudah tidak ada kamipun menuju parkiran dan bergegas untuk pulang.

\section{Data 5}

Penampilanku mulai kurubah dan dulu aku selalu ingin main-main aku kurangi walaupun tidak bisa hilang sepenuhnya, Berdasarkan tulisan siswa tersebut terdapat kata kurubah adalah pemakaian kata yang keliru. Kata tersebut bukan berasal dari kata dasar rubah, melainkan ubah. Interferensi yang terjadi adalah penggunaan kata kurubah. Jadi, seharusnya dalam tulisan tersebut diganti menjadi berubah bukan kurubah.

\section{Data 6}

Suatu hari pas liburan, jam menunjukkan pukul 07.00 WIB aku dan ibu pergi ke ladang.

Kalimat di atas terdapat kata pas, suatu hari pas liburan. Penggunaan kata pas adalah interferensi yang dilakukan oleh siswa. Kata pas tidak ada dalam KBBI. Pas diartikan ketika oleh siswa. Jadi, perbaikannya kalimat tersebut seperti di bawah ini. 
Suatu hari ketika liburan, jam menunjukkan pukul 07.00 WIB aku dan ibu pergi ke ladang.

\section{Data 7}

Hau, jangan begitu kita dengan Sita.

Dalam kalimat tersebut terlihat penggunaan interjeksi dalam penggunaan bahasa Indonesia. Interjeksi adalah ungkapan perasaan, ekspresi seseorang ketika berujar. Interjeksi tersebut merupakan salah satu interferensi yang terjadi pada siswa SMPN 1 Katingan Tengah. Interjeksi merupakan serpihan bahasa ibu yang masuk dalam bahasa Indonesia. Kaidah seperti merupakan penyimpangan terhadap bahasa yang digunakan.

Interjeksi yang ditemukan selain data di atas adalah seperti di bawah ini.

\section{Data 8}

Akui, banyaknya tugas hari ini.

May ku Sita.

Penggunaan kata akui dalam tuturan tersebut menggambarkan ungkapan perasaan penutur.

Kata akui dan may merupakan interjeksi bahasa Katingan. Dapat dikatakan bahwa tuturan siswa SMPN 1 Katingan Tengah merupakan interferensi akibat pengaruh bahasa pertama/ibu.

\section{Data 9}

Saya senang mempunyai teman-teman yang baik, lucu, konyol, dan sebagainya di kelas VII D ini. Teman-teman saya ini sangat the best deh.

Berdasarkan data di atas terdapat serpihan yang berasal dari bahasa Inggris, yakni the best. Serpihan tersebut merupakan interferensi pada tingkat kalimat. Data tersebut merupakan penyimpangan bahasa yang dilakukan oleh siswa SMP dengan memasukkan sistem bahasa lain ke dalam bahasa yang sedang digunakan, yaitu bahasa Indonesia. Selain itu, interferensi yang serupa juga terdapat dalam tulisan siswa seperti di bawah ini.

\section{Data 10}

Setelah aku beristirahat sampai pukul 03:00 kami kumpul lagi di beskem kami.

Berdasarkan kalimat dalam tulisan siswa tersebut, siswa dengan sengaja menggunakan serpihan kata lain, yakni beskem. Penggunaan kata beskem adalah serpihan bahasa Inggris, yang seharusnya yang dimaksud adalah base camp. Sistem bahasa lain yang masuk ke dalam kalimat di atas mengakibatkan terjadinya interferensi dalam bahasa Indonesia.

\section{Data 11}

Senang melihat orang naik kelotok, di sana juga ada orang yang mancing, marengge, dan mandi.

Berdasarkan tulisan siswa di atas terdapat serpihan kata berasal dari bahasa Katingan. Penggunaan kata marengge merupakan interferensi bahasa ibu. Marengge adalah salah satu cara untuk menangkap ikan dengan menggunakan jaring yang dibentang dengan bambu, kemudian ditenggelamkan ke dalam sungai dan setelah itu diangkat. Kekurangan dan ketidaktahuan terhadap kosakata bahasa Indonesia mengakibatkan interferensi dalam bahasa Katingan. Adanya serpihan bahasa pertama dalam penggunaan bahasa kedua tersebut merupakan kesalahan berbahasa yang dilakukan oleh siswa SMP.

\section{Data 12}

Aduh tanganku mener menulis terus.

Hal serupa juga ditemukan dalam kalimat di atas. Penggunaan kata atau serpihan kata yang berasal dari bahasa pertama digunakan dalam penggunaan bahasa kedua. Hal ini mengakibatkan adanya interferensi dalam bahasa Indonesia. Penggunaan kata mener merupakan interferensi sintaksis dalam 
bahasa Indonesia. Padanan kata mener dalam bahasa Indonesia adalah kesemutan. Perbaikan kalimat di atas adalah Aduh tanganku kesemutan menulis terus.

\section{Data 13}

Kamipun pulang, perjalanan sangat ceria, tetapi ada ular yang lagi menyebarang jalan.

Dari tulisan siswa terdapat kata menyebarang dalam bahasa Indonesia merupakan penyimpangan bahasa akibat pengaruh bahasa ibu. Kata dasar tersebut adalah seberang dan diberikan awalan me-. Kata tersebut berawalan $s$ sehingga apabila diberikan awalan akan luluh. Penggunaan serpihan bahasa ibu membuat kalimat ini ditemukan interferensi. Kata dasar menyebarang adalah sebarang, sehingga bila diberikan awalan me- menjadi menyebarang. Dalam penggunaan bahasa Indonesia, seharusnya kata tersebut adalah menyeberang. Perbaikan kalimat tersebut seperti di bawah ini.

Kami pun pulang perjalanan sangat ceria tetapi ada ular yang lagi menyeberang jalan.

\section{Kesimpulan}

$\begin{array}{lcr}\text { Interferensi } & \text { sintaksis } & \text { adalah } \\ \text { gangguan yang terjadi akibat } & \text { adanya } \\ \text { penyimpangan } & \text { struktur } & \text { kalimat. }\end{array}$

Berdasarkan hasil analisis ditemukan dua jenis interferensi sintaksis yang terdapat dalam bahasa lisan dan tulisan siswa SMPN 1 Katingan Tengah antara lain: (1) Interferensi frasa terhadap bahasa Indonesia dan (2) Interferensi kalimat terhadap bahasa Indonesia.

\section{DAFTAR RUJUKAN}

Kridalaksana. 2001. Kamus Linguistik. Edisi Ketiga. Jakarta: PT Gramedia Pustaka Utama.

Rafiek, Muhammad. 2007. Sosiologi Bahasa: Pengantar Dasar Sosiolinguistik. Banjarmasin: FKIP Universitas Lambung Mangkurat Banjarmasin.

Wahyu. 2012. Metodologi Penelitian Kualitatif. Banjarmasin: FKIP Universitas Lambung Mangkurat Banjarmasin.

Yanti, Prima Gusti. 2011. Interferensi Bahasa Betawi dalam Pemakaian Bahasa Indonesia di dalam Surat Kabar Pos Kota Jurnal Bahasa Alinea FBS-UNJ Fakultas Bahasa dan Seni Universitas Negeri Jakarta. 